\title{
Creativepreneur in Era 5.0: Concept and New Path of Communication in Indonesian Urban Toys Artist
}

\author{
Rani Chandra Oktaviani ${ }^{1}$, Fadlin Nur Ichwan ${ }^{2}$ \\ Faculty of Communication Studies, London School of Public Relations, Jakarta, Indonesia ${ }^{1}$, \\ London School of Public Relations, Jakarta, Indonesia ${ }^{2}$ \\ \{rani.co@1spr.edu ${ }^{1}$, fadlin.ni@1spr.edu $\left.{ }^{2}\right\}$
}

\begin{abstract}
This research was conducted by looking at the problem that globalization and digital networks as communication channels make a significant aspect in urban toys sales competition. The entry of producers/urban toys artists from abroad, makes it a challenge where the local target market is more familiar with foreign producers/ artists. Amid global competition, several artists and the Indonesian urban toys toy community of entrepreneurs began to change the concept of entrepreneur and communication channels with new alternative strategies. Seeing the above symptoms, this study was conducted with the aims 1) Analysing the new strategies of urban toys entrepreneurs from local Indonesian artists. 2) Analysing the characteristics of concepts and message content of products/works 3) Analysing changes in communication channels with a digital approach as a form of transformation from Indonesian urban toys entrepreneurs. This study uses Opportunity-Based Theory and is combined with the concept of communication strategy. The methodology used is qualitative and analysed by using qualitative data coding. The results of this research found that several local Indonesian Entrepreneurs/ Artists had implemented digital (Dynamic Entrepreneur) communication strategies. Another significant finding is that Indonesian urban toys entrepreneurs have begun to apply digital communication lines that are able to cut the mass production process from communicating with producers, distributors, customers, to reviewers, all through e-commerce communication networks. The implications of this study indicate that era 5.0 can be used as an innovation entrepreneurship, where humans act as man behind the concept, communication as a process, and digital systems as a machines for production until promotion.
\end{abstract}

Keywords: Entrepreneurs; Communication; Urban Toys; Globalization

\section{Introduction}

This research was conducted by the emergence of era 5.0, where entrepreneurs began to enter the digital climate, competition from foreign countries that were better prepared in the digital system made Indonesian entrepreneurs begin to adapt the system. one of the entrepreneurship sectors that is currently being pushed is in the creative industry sector. As stated by the Minister of Finance, she hopes that the creative industries can increase and 
contribute greatly to Indonesia's economic growth. The concentration of the growth of the creative industry was also stated by the President of the Republic of Indonesia concerning the important role of the creative industry and digital economy in driving the Indonesian economy. In addition, the president stated that currently to encourage this matter, the Minister of Industry already has an industrial plan 4.0 with 10 strategies, including improvement of supply chains. Although considered important and has good potential, the contradiction is that there is still a slight increase in contributions in the creative industry sector, as in the following data; In 2015, the creative economy contributed $7.39 \%$ to GDP or IDR 852.56 trillion. Increased slightly in 2016 which amounted to $7.44 \%$ of GDP or with a value of Rp922.59 trillion [1].

One of the businesses in the creative industry is the toy industry, which is now better known as urban toys or designer toys is a business opportunity that has great potential. Outside the country itself, the development of toy companies is quite a lot and there are even artists who focus on only making designer toys or Art Toys, and it turns out that these developments can make a good contribution to the country. Like the Super Seven company that specializes in only making Kaiju or Monsters, or Crazy Label from Hong Kong or Muttpop from America, Kusovinyl, or Strange.Co. Not only companies that produce toys in bulk, the artist himself is now developing into an entrepreneur and making a company with his own name. Some of the overseas toy manufacturers that are developed by the artist are Tokidoki or Ugly Dolls, which are currently growing rapidly and are well known globally. Once Japanese toy companies such as Bandai or Medicom who are experienced in making toys from the 80 s also make figure Toys/urban toys [2].

This research was raised by looking at the problem that globalization and digital networks as marketing communication channels make a significant aspect in urban toys sales competition. The entry of producers/urban toys artists from abroad, makes it a challenge where the local target market is more familiar with foreign producers/ artists. Amid global competition, the local Indonesian urban toys artist, began to run a concept-based local and bring Indonesian Culture [3]. Several artists and the Indonesian urban toys community of entrepreneurs began to change the concept of entrepreneurship and marketing communication channels with new alternative strategies. Starting the development of the distribution patterns of urban toys activists, previously it was still done independently or through a concept store. But apart from these two ways, toy designers usually do exhibitions or launching toys that are useful as a media for promotion and distribution of their urban toys. For its market in Indonesia, it is increasing. This is evidenced by the number of new urban toys artists that have sprung up, as well as the emergence of the Urban Toys Stage which is a reference for the advancement of Indonesian urban toys [4].

From the background explanation above, it can be formulated and a research question that is, how are the characteristics of entrepreneurship and the implementation of the urban toys artist communication strategy in developing business in the era of disruption? Seeing the above symptoms, this study was conducted with the aims: To analyse the new strategies of urban toys entrepreneurs from local Indonesian artists. To analyse the characteristics of concepts and message content of products/works. To analyse changes in communication process and channels with a digital approach as a form of transformation from Indonesian urban toys entrepreneurs.

\section{Method}


The methodology used is qualitative with data collection techniques through in-depth interviews, the key informants on this research were several urban toys artists/entrepreneurs in Indonesia with predetermined criteria bellows: 1) Senior artist urban toys. 2) Urban toys artist who runs the urban toys business (Start-up). 3) Has been running the urban toys business for more than 5 years. 4) Has sold they works to foreign countries. 5) Active using social media and make online sales through the internet.

This research analysed using qualitative data coding model for the thematic analysis process. It consists of three link stages or 'streams' there are data reduction, data display and data conclusion-drawing/verifying observing data and connect it with the conceptual [5]. Qualitative approaches give room to a deeper understanding of the subject matters as they exist in their own unique environment and analysis will aid thorough understanding of qualitative data interpretation[6].

\section{Results and Discussions}

This research sees that urban toys artists who are also entrepreneurs, do an OpportunityBased approach where as stated that this approach is more entrepreneurs see changes, for example in the current context of the digital era and technological developments, they actually see these changes as opportunities. Even some artists even use it to the maximum. when referring to what was delivered by Drucker. Where through this approach entrepreneur are looking for change, respond to it, and exploit it as an opportunity [7]. The following was delivered by an urban toys artist who stated that: "oh... with the existence of technology it has been made easier, so we can sell our products overseas easily, either through Instagram or sales sites"

There is interesting finding in this research, that in maximizing its business through a digital system, there are Indonesian urban toys artists who get the opportunity by maximizing the entire business process just by building good communication with overseas urban toys businesses. According to the artist, the importance of the concept and consistency of the artist in making works of urban toys will be able to create a special attraction from foreign producers. then no less important is the need for intensive and persuasive communication with business people abroad [8], from this experience an Indonesian urban toys business has the opportunity to be handled by an overseas producer, starting from making material for urban toys, producing mass works, doing custom collaborations toy with famous artists from several foreign countries, to do the marketing of urban toys products are from these foreign manufacturers.

\subsection{New strategies of urban toys entrepreneurs from local Indonesian artist.}

Another significant finding is that Indonesian urban toys entrepreneurs have begun to apply digital communication strategy that are able to cut the mass production process from communicating with producers, distributors, customers, to reviewers, all through e-commerce communication networks. The following can be illustrated through technology, in fact entrepreneurs can actually take advantage of more opportunities even to minimize business capital. 


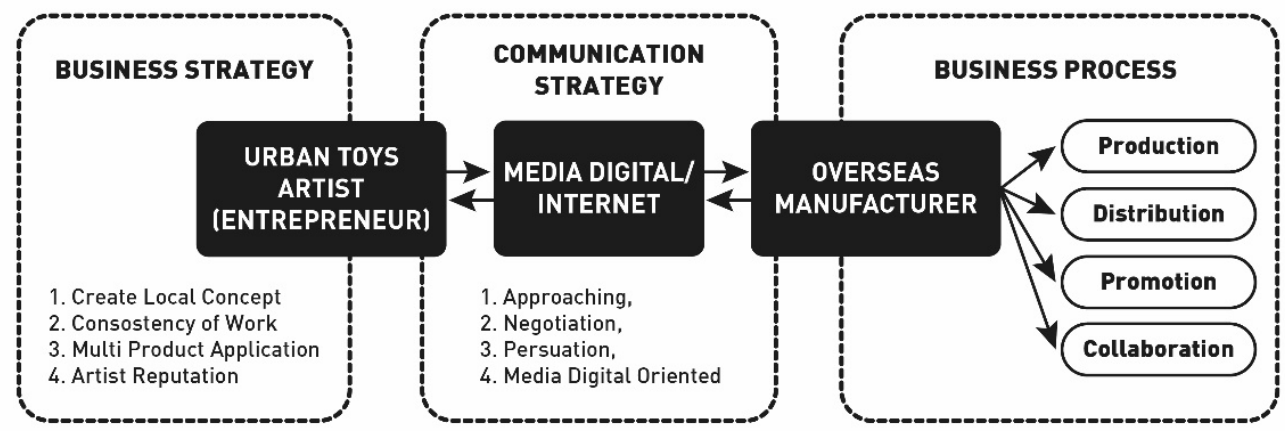

Fig 1. Business channel entrepreneur urban toys based in the era digital

The results of this research also found that several local Indonesian entrepreneurs/artists had implemented digital in Dynamic Entrepreneur characteristic actually in dynamic networking [9]. That characteristic has advantages such as; budget and time efficiency in the midst of limited capital, opportunity to expand, be able to compete global and have a good positioning. Other characteristics that are indicators that urban toys are more directed to dynamic entrepreneurs such as: Urban toys artists who are more young generation, they think that their work should be enjoyed not only by Indonesian people but they are trying to penetrate the global market. this is as conveyed by the speakers as follows: "We also end up targeting foreign markets or in other words going global, in addition to our aim to sell works, yes, sometimes foreign appreciation of Indonesian local products is better. Sometimes even Indonesians will buy our works if they are thrown out country."

In addition, they also see the conditions and situations, one of which is a form of competition, local artists will have great competition if playing in the country especially if selling with conventional systems such as participating in exhibitions, or selling through stores. so feel the need to create unique works and have the opportunity to be taken abroad using a number of digital marketing techniques such as entering join eBay, open the sales website, registering a digital sales application and utilizing social services to conduct auctions and pre orders. Utilization of all lines of digital devices assessed by artists can help sales and be able to compete globally [10].

\subsection{Concept of Strategic Communication.}

Whereas the characteristic concept of the works of Indonesian urban toy entrepreneurs is an original platform created with social-themed ideas according to Indonesian conditions and the use of cultural icons as a differentiator from foreign producers. Determination of the concept and positioning of the work is part of the communication strategy process, several forms of communication carried out in urban toys entrepreneurs from Indonesian artists can be identified as follows:

Artists need to make the image and concept of the work carefully, because actually in this business, the main strength is the Concept of Work. Artists usually have set the scope of the concept, the concept will only be used as urban toys (mono-product) or it will be developed in parallel with the development of other products such as t-shirts, artwork, tote bag etc. (multiproduct). this seems to be conveyed by the informant: "Yes, we usually make concepts from the beginning, and this is important, sometimes we have come to think that if our urban toys concept is good, we can explore other products, like making t-shirts, tote bag artwork, 
because urban toys are actually part of urban art, then it can be developed ... but yes, it must be determined first".

Beside that Indonesian artist try to create the persuasive technique, in their concept with stimulate people with other products beside the urban toy as their core product. Refer to the literature said that the entrepreneurs like must persuade others and understand persuasion and legitimacy [11].

\subsection{Marketing Communication Strategy}

In the digital age, marketing communication is demanded to be simpler and more creative [12]. According to the artist they actually no longer require a lot of effort, but rather can create a unique communication gimmicks, that is enough, because henceforth it only needs to be continued in social media. In addition, the need to be active in social media is also important because through that, the market will get to know the artist and his work. The interesting finding in this research object is that there are two aspects to marketing strategy, namely the product (urban toys) and the artist (work reputation). This finding is in line with the statement of the informant of this study who said: "We have to be able to be open minded like abroad and our signature must be able to be developed on various platforms. In addition, the role relay is also needed along with the development of the age of these industry must be filled with many young people and sociable. Because if for me... the gap is too far away with developments now. To start branding, bombing can also be started using social media like Instagram etc. and it is likely that other scenes will glance."

Here are some media platforms that can be used in marketing products by urban toys from Indonesian artists:

Table 1. Media Platform Used by Urban Toys Artist

\begin{tabular}{ll}
\hline \multicolumn{1}{c}{ Media Digital } & \multicolumn{1}{c}{ Utility } \\
\hline Instagram & Engagement with colleagues, followers, fellow artists \\
Facebook & Open networks for, resellers, communities, etc. \\
Free Online Sales Website & Market Expansion \\
e-Bay, PayPal & Reach Global Market, Virtual Money \\
Android Application & Reach Indonesian Market \\
Website, Blog Spot & Showroom Product, Concept Display, Media Review \\
\hline
\end{tabular}

Source: Primary Data 2019

Based on the results of this study, urban toys artists can be seen as entrepreneurs with a creative and innovative basis. The creative aspect comes from the artist being the creator of the artwork, but what makes innovation is the process of promoting their work [13]. If it refers to the entrepreneurial process, one of the things that has been applied is to recognize opportunities and seek information in marketing and product concept formation in the new era [14]. urban toys artists are considered quite responsive in seeing the opportunities that exist. Technological development is not used as a competitive threat, but rather an opportunity to reduce capital and cut business chains. Entrepreneurial innovation is also marked by the use of minimal resources; this will certainly further reduce the cost of human resources. Some artists even use three-dimensional digital printing to reduce production costs from third parties. The above findings reinforce that the urban toys business has actually applied the dimension of business effectiveness and has greatly utilized the digital era for the distribution of their work. With the growth and advancement of technologies, the impact of cutting edge technologies such as information technology on the business environment cannot be overlooked so they 
need to use of innovative strategic communication and marketing process with some features of media digital [15].

This research sees that the actual urban toys artist does not fully make a business as a digital entrepreneur, because the product itself is not system or service based. but what's interesting to discuss and emphasize in this research is how an entrepreneur can see technological change as a business opportunity and not a threat. The Indonesian artist create the new idea to develop their business as literature said that for entrepreneurs in the field of information and communication technologies there is implementation conditions: availability of ideas for structuring of information flows. Based on Opportunity-Based theory in entrepreneurship studies, technological change will be very beneficial when two main concepts of entrepreneurship can be utilized, namely creative concepts, both in business strategy, marketing, business processes, and networking. Social networking allows businesses to gain access to resources and also aid to increase the customer and supplier contacts, bring to light where resources and funding are available, promote innovation and help in the cultivation of strategic partnerships [16]. Artist urban toys as entrepreneur are pushed to develop strategic flexibility using communication capabilities as dynamic adaptation. In the previous study mention that strategy is carried out to avoid the risks of relying mainly on static flexibility or inventory. The logical corollary of their work is that dynamic flexibility is a key feature to strategic entrepreneurship [17].

\section{Conclusions}

The implications of this research indicate that era 5.0 can be used as an entrepreneurial innovation, where humans act as human beings behind concepts, communication as processes and strategies, and digital systems as channels to third parties that will help maximally support business processes from production, promotion to business collaboration.

While the theoretical implications of the results of this study indicate that the digital era is not a global threat, Opportunity-Based Theory represents a condition where an urban toys entrepreneur can see business opportunities. Adaptation from changes in technology and changes in media platforms, can be a strength of its own business. At the stage of opportunity utilization, some urban toys artists are considered to be at the level of opportunity exploitation, the intended exploitation is to suppress business processes that are carried out by themselves. A third party that is used as a partner or manufacturer can be utilized to the full, and the artist only has to wait or monitor the business process. On the other hand, the characteristics of these entrepreneurs also have some risks, such as if there is a business process that is wrong, does not go according to agreement, and falsification of works, or the continuing production of works of urban toys without the knowledge of the artist. This has indeed become one of the characteristics of dynamic entrepreneurs that is risk taking.

\section{References}

[1] Uly, Y. A. (2018, November 7). economy.okezone.com/read. Retrieved fromeconomy.okezone. com: https: //economy.okezone.com/read/2018/11/07/320/1974739/sri-mulyani-sebut-industri kreatif-jadi-andalan pertumbuhan-ekonomi 
[2] www.bandungmagazine.com/analysis. (2015, November 25). Retrieved from bandungmagazine

http://www.bandungmagazine.com/analysis/designer-toyssebagai-mediumbaru

[3] Oktaviani, R. C., \& Ichwan, F. N. (2018). Urban toys as a new alternative media to promote Indonesian culture. Jurnal Komunikasi: Malaysian Journal of Communication, 34(4), 303-318. https://doi.org/10.17576/JKMJC-2018-3404-18

[4] Socamedia. (2018, May 7). socamedia.id/artikel. Retrieved from socamedia.id: https://socamedia.

$\mathrm{id} /$ artikel /urban-toys-dan-perkembangannya

[5]. Alhojailan, M. I., \& Ibrahim, M. (2012). Thematic Analysis : A Critical Review of Its Process and Evaluation.West East Journal of Social Sciences-December (2012), 39-46.

[6]. Akinyode, B. F., \& Khan, T. H. (2018). Step by step approach for qualitative data analysis. International Journal of Built Environment and Sustainability, 5(3), 163-174. https://doi.org/10.11113/ijbes.v5.n3.267

[7]. Nkansah, S. K. (2011). Entrepreneurship theories and Empirical research: A Summary Review of the Literature. European Journal Business and Management, 3(6), 1-9.

[8]. Redien-Collot, R., \& Lefebvre, M. R. (2015). Communication and Entrepreneurship: Influence Tactics in Business Support Situations. International Review of Entrepreneurship, 13(4), 269-297. Retrieved from http://search.ebscohost.com/login.aspx?direct=true\&db=ent\&AN=111811647 \&site $=$ ehost-live

[9]. Engel, Y., Kaandorp, M., \& Elfring, T. (2017). Toward a dynamic process model of entrepreneurial networking under uncertainty. Journal of Business Venturing, 32(1), 35-51. https://doi.org/10.1016/j.jbusvent.2016.10.001

[10]. Sahut, J.-M., Iandoli, L., \& Teulon, F. (2019). The age of digital entrepreneurship. Small Business Economics, (September). https://doi.org/10.1007/s11187-019-00260-8

[11]. Spinuzzi, C. (2017). Introduction to Special Issue on the Rhetoric of Entrepreneurship: Theories, Methodologies, and Practices. Journal of Business and Technical Communication, 31(3), 275-289. https://doi.org/10.1177/1050651917695537

[12]. FILLIS, I., \& RENTSCHLER, R. (2010). the Role of Creativity in Entrepreneurship. Journal of Enterprising Culture, 18(01), 49-81. https://doi.org/10.1142/s0218495810000501

[13]. Sattari, B., \& Mehrabi, J. (2016). Model of marketing innovative strategies in international entrepreneurship: A global business environment. Journal Asian Social Science, 12(10), 76-91. https://doi.org/10.5539/ass.v12n10p76

[14]. Kraus, S., Harms, R., \& Fink, M. (2010). Entrepreneurial marketing: Moving beyond marketing in new ventures. International Journal of Entrepreneurship and Innovation Management, 11(1), 19-34. https://doi.org/10.1504/IJEIM.2010.029766

[15]. Gontareva, I., Chorna, M., Pawliszczy, D., Barna, M., Dorokhov, O., \& Osinska, O. (2018). Features of the entrepreneurship development in digital economy. TEM Journal, 7(4), 813-822. https://doi.org/10.18421/TEM74-19

[16]. Jagongo, A., \& Kinyua, C. (2013). The Social Media and Entrepreneurship Growth. International Journal of Humanities and Social Science, 3(10), 213-227. Retrieved from www.ijhssnet.com

[17]. Renato, P., \& M. Naguib, O. (2016). Strategic entrepreneurship and dynamic flexibility: Towards an integrative framework. International Journal of Organizational Leadership, 5(4), 307-312. https://doi.org/10.33844/ijol.2016.60286 
